\title{
LA ENUNCIACIÓN POÉTICA EN LA OBRA DE CARMEN MARTÍN GAITE
}

\author{
THE POETIC STATEMENT IN THE WORK \\ OF CARMEN MARTÍN GAITE \\ José TERUEL BENAVENTE \\ Universidad Autónoma de Madrid \\ jose.teruel@uam.es
}

Resumen: Este artículo analiza una modalidad de la obra de Carmen Martín Gaite poco atendida por la crítica: su poesía, y demuestra que no es una vertiente marginal de la autora, sino que complementa e ilumina su labor narrativa, ensayística y de corte autobiográfico, como los Cuadernos de todo. Martín Gaite entendió que la enunciación lírica, por encima del uso del verso o de la prosa, radica en un tratamiento temporal de la experiencia humana, que hace caso omiso de una imagen del tiempo concebida como un continuum y saca a flote los vértices decisivos de la existencia.

Palabras clave: Carmen Martín Gaite. Enunciación lírica. Escritura transversal. Poesía. Prosa.

Abstract: This article analyzes a mode in Carmen Martín Gaite's work
which has received little critical attention: her poetry. And shows that it
is not a marginal aspect, but rather that it complements and illuminates
her narrative, essayistic and autobiographical texts, such as Cuadernos de
todo. For Martín Gaite the poetic text, beyond the use of verse or prose,
consists of a temporal treatment of human experience which eschews an
image of time conceived as a continuum and focuses on the fundamental
aspects of existence.

Key Words: Carmen Martín Gaite. Lyrical statement. Transversal writing. Poetry. Prose. 
Este artículo se propone el análisis de la poesía completa de Carmen Martín Gaite siguiendo la trama autobiográfica o del paso de la edad con que la autora articuló Después de todo. Poesía a rachas (1994): "Poemas de primera juventud", "Poemas posteriores" y "Después de todo". Desde esta ordenación sigue la pauta de la bibliografía, aún escasa, sobre esta vertiente de su obra (Persin [1990], Niemöller [2004], Teruel [2007], Jurado Morales [2011] y Wood [2014]). Pero este trabajo quiere dar un paso más entre las aportaciones citadas con el cotejo de los cuadernos manuscritos que están a disposición del investigador en su Archivo de la Biblioteca Digital de Castilla y León, y, sobre todo, desde el estado de la cuestión que ha supuesto la edición anotada en siete tomos de sus Obras completas (entre 2008 y 2019). Esta edición ha confirmado, entre otras cuestiones, los vasos comunicantes y la permeabilidad entre todos los géneros literarios que cultivó la autora salmantina, por ello este artículo se plantea la relación de su poesía con el resto de su obra y la consideración de lo poético en su producción literaria como "una actitud de enunciación, más que como un estado del lenguaje" (Genette, 1993: 20).

\section{POEMAS DE PRIMERA JUVENTUD}

Carmen Martín Gaite comenzó su andadura e historia literaria escribiendo y publicando poesía. Lo demuestran tres cuadernos de 1947 conservados en su Archivo y la publicación, ese mismo año, de "La barca nevada" en la revista universitaria salmantina, Trabajos y Días (Martín Gaite, 2010: 675-76). El deseo de detenerse con una nueva mirada ante las cosas habitualmente vistas de prisa, la invocación - tan recurrente en la poesía escrita en España desde 1944 - a un Dios huidizo y a quien se requiere como posible interlocutor de preguntas sin respuesta, el desacuerdo entre lo que se hace y lo que se sueña, y las premoniciones sobre su futuro son los motivos recurrentes de estas primeras composiciones: "Mi primera fuente de inspiración literaria fue la curiosidad por el tiempo futuro, que a veces se insinuaba como la tentación de asomarse a un abismo del que aún nada se sabe", explica Martín Gaite en su conferencia "Los viejos en la literatura" (2017: 1029).

Dos de estas libretas, auténticos "cuadernos de todo" avant la lettre, tienen un rótulo propio: la primera con el título de El paraíso recobrado; 
la segunda es una Agenda médica, que le regaló su tío Vicente Gaite, el médico de la familia, según se desprende de El libro de la fiebre. Las composiciones de estos cuadernos están fechadas, a modo de diario, entre agosto de $1947 \mathrm{y}$ los primeros meses de 1948, y nos ofrecen los ante-textos (Blasco, 2011: 31-46) de diez poemas que formarán parte de $A$ rachas desde su primera edición en 1976 ("Telarañas", "Certeza", "Canción rota", "Callejón sin salida" [aún sin título], "Por el mundo adelante" [aquí titulado "Gritos"], "Pídeme que esté alegre" [aún sin título], "Muerte necia" [sin título], "En mi vejez" [definitivamente titulado "Tiempo de flor"], "Desembocadura", "Me pesas como un fardo" y "Destello") y dos de la tercera edición de 1986 ("Domingo por la tarde" y "Espiga sin granar"). La relación de estas primeras versiones con las definitivas fluctúa entre la proximidad ("Certeza", "Callejón sin salida") y la completa diferencia léxica, sintáctica y estrófica ("Domingo por la tarde", "Espiga sin granar"). Otros poemas son solo breves anotaciones en estos cuadernos que serán desarrolladas después ("Pídeme que esté alegre", "Muerte necia"). Por ello podemos colegir que Carmen Martín Gaite no solo seleccionó sino también reconstruyó en 1976 los poemas de las libretas de Salamanca. Pero el mayor interés de estos cuadernos autógrafos de los "Poemas de primera juventud" estriba en comprobar cómo la autora componía sin las constricciones de la versificación regular silábica. Los poemas parecen escritos en prosa y los versículos semejan párrafos. Escojo como ejemplo el ante-texto de "Certeza" (un poema que registra además un asombroso paralelismo textual entre la primera versión y la definitiva) para comprobar el contraste entre los tres versículos de la versión de 1947, en El paraíso recobrado, con la tendencia al isosilabismo de la versión definitiva de 1976. Nos interesa esta ametría de los poemas juveniles en primera versión, porque pudiera ser un indicio de cómo para Martín Gaite la poesía no radicaba en la contención de la versificación silábica, sino en un ritmo interior, que rescataba una instantánea, un estallido emocional: "mi estallido de anhelos", leemos en la primera versión de "Canción rota", con lo que ya nos aproximamos a una concepción de la escritura poética muy acorde con la escritura transversal entre prosa y verso, entre narración y enunciación lirica que propondremos en este artículo: 
[Primera versión]

Habéis empujado hacia mi estas piedras. Me habéis amurallado para que me acostumbre.

Pero aunque ahora no pueda ni intente ni pretenda dar un paso. Yo sé que es por allí por donde quiero ir, sé por dónde se va. Mirad, os lo señalo:

Por aquella ranura de poniente (Martín Gaite, 1947-1948: 44).

[Versión definitiva]

Habéis empujado hacia mí estas piedras.

Me habéis amurallado

para que me acostumbre.

Pero aunque ahora no pueda

ni intente dar un paso,

ni siquiera proyecte fuga alguna,

ya sé que es por allí

por donde quiero ir,

sé por dónde se va.

Mirad, os lo señalo:

Por aquella ranura de poniente (Martín Gaite, 2010: 616).

De la Agenda médica reparo en una breve composición, sin título, que apunta al lugar que para esta joven de veintiún años ocupó esta escritura "a rachas". Carmen Martín Gaite comenzó a escribir sus primeros poemas y cuentos como una forma de huir hacia dentro, de expresar su extrañeza ante lo cotidiano. Brechas en la costumbre fue el expresivo y provisional título que la autora había prefigurado para la recopilación en un volumen de sus cuentos de la primera época (Martín Gaite, 2016: 786). Y, sobre todo, las brechas en el muro de las costumbres responden a su comprensión de la literatura en general y de lo fantástico en particular, entendidos como sinónimo de una aparición que va a provocar un quiebro en el punto de vista ${ }^{1}$ :
Es como otra morada
como un humo.
Me salen al paso
llenos de rocio
mis versos por el camino
cuando se apaga el rumor
de las ajenas voces

\footnotetext{
${ }^{1}$ Respetamos la puntuación de la autora.
} 
de los pasos ajenos

que retumban

que se enzarzan alrededor (Martín Gaite, 1948: 73).

Con "La barca nevada", una estudiante que firmaba con el nombre de Carmiña inauguraba en enero de 1947, en Trabajos y Días, su historia literaria (Romero López, 2002: 239-256). El poema inspirado en una instantánea del fotógrafo de El Adelanto, Pepe Núñez (padre del poeta Aníbal Núñez), recreaba la imagen de una barca prisionera entre los hielos del Tormes y exhortaba a través de un escolar carpe diem a esperar el deshielo inminente del río. Esta simbólica composición sobre la barca atrapada, aguardando una próxima primavera, no será recogida por su autora en ninguna recopilación posterior de su poesía, pero sí fue recordada como primer texto publicado en vida en su discurso "Las glorias y las memorias" (2016: 1007), con motivo del Premio Castilla y León de las Letras.

Todos los poemas que acabamos de citar, impregnados de malestares íntimos, preocupaciones existenciales y veladas protestas, compartían un aire de familia con los primeros escritos de la mayoría de sus compañeros de promoción universitaria, por entonces fieles admiradores del libro del jovencísimo poeta José María Valverde, cuyo Hombre de Dios (1945), prologado por Dámaso Alonso, había hecho furor en los ambientes universitarios del segundo lustro de 1940. Como se puede comprobar si comparamos "La barca nevada" con "Canción a sí mismo", firmada por Agustín García [Calvo], poemas que coinciden en la misma imprecación simbólica a un río helado y que comparten la misma página de Trabajos y Días (número 5, enero-febrero de 1947, s.p.).

Idéntico tono intimista y angustiado traspasará la prosa poética de sus primeros cuentos ("Desde el umbral" e "Historia de un mendigo") y de su primer artículo ("Vuestra prisa"), tono que comenzará a virar gracias a "los consejos" de sus dos hombres-musa: Ignacio Aldecoa y posteriormente Rafael Sánchez Ferlosio, según reconoció la propia Martín Gaite (2016: 648). Aldecoa publicó en el mismo 1947 su primer cuadernillo de poesía Todavía la vida y dos años más tarde el Libro de las algas, que con sus imágenes postistas desentonaba abiertamente con el monocorde registro neorromántico dominante. Ferlosio le inculcó ya en Madrid y al filo de los años cincuenta su poética de la exactitud descriptiva de ambientes y 
conductas.

Las primeras versiones de los poemas juveniles están fechadas entre 1947 y 1949. Por la información que se desprende de la nota preliminar —titulada nuevamente "A rachas" y escrita en los últimos meses de su vida - para una selección de sus Poemas, sabemos que algunas de sus composiciones juveniles fueron destruidas y tuvieron que ser reelaboradas de memoria: "Años más tarde, al recordar, los que se me quedaron más grabados, los escribí cambiándolos un poco. Supongo que aquellos que sepultó el olvido será porque merecían tal paradero" (Martín Gaite, 2010: 595). Y en esa amalgama entre libro de memorias, ficción y ensayo que es El cuarto de atrás encontramos esta confesión coincidente con la del poema "Los libros que ahora busco":

- He quemado tantas cosas, cartas, diarios, poesías. A veces me entra la piromanía, me agobian los papeles viejos. Porque de tanto manosearlos, se vacían de contenido, dejan de ser lo que fueron.

Me quedo callada. La última gran quema la organicé una tarde de febrero, estaba leyendo a Machado en esta misma habitación y me dio el arrebato (Martín Gaite, 2008: 986).

No dudamos de que en esa imprecisa "tarde de febrero" (rememorada en El cuarto de atrás, tras leer el elogio "A Xavier Valcarce", en el que Antonio Machado exhorta a no cultivar la nostalgia para acogerse impasible a lo que aún pudiera ofrecer el día) ella quemara entre otros "papeles viejos" algunos de sus poemas, pero lo verdaderamente significativo reside en que esas cartas, diarios y poesías estuvieran encerrados bajo llave en un mismo lugar, en el "baulito de hojalata" que fue antes de su madre (2008: 986), como escritos pertenecientes a un género semejante y que era necesario custodiar por concernir al secreto: a la escritura más íntima.

La conciencia del tiempo vista desde distintos puntos de observación es el motivo recurrente de los poemas del ciclo de juventud: desde la sensación de tener aún mucho tiempo que perder o para demorarse en "Canción rota" y "Tiempo de flor", hasta el tiempo vivido como confinamiento y acoso en "Domingo por la tarde", donde se perfila el dibujo de la chica desarraigada que pasea sin rumbo, tratando de descifrar signos por la ciudad estancada (La charca fue el simbólico título inicial con claras resonancias unamunianas, que Martín Gaite barajó para Entre visillos). La metáfora del lugar ominoso y cerrado pareció ir apoderándose 
de la imaginación de los jóvenes escritores de 1950. Esta última dimensión del tiempo vivido como rechazo a lo tangible otorga un aire fuertemente existencial al ciclo juvenil. Los descontentos vitales e íntimos - la rutina y la experiencia de los días "tontos", de la muerte pequeña o diariaevidencian también otro tipo de malestares de corte más social o público. La poesía juvenil de Martín Gaite nos ilumina sobre su concepción y su práctica narrativa del realismo, que consistió en descifrar lo real más que en decir la realidad (Barthes, 1974: 60). Como en sus cuentos de la década de 1950, en los poemas "Nubes", "Por el mundo adelante" y "Certeza", el personaje poemático emprende fugas imaginarias y evidencia sus ansias de libertad. Una libertad percibida más como añoranza que como búsqueda heroica. La propia Martín Gaite ha ofrecido retrospectivamente una clave de lectura que despeja muchos de sus poemas juveniles y nos ayuda a entender ese doble malestar, tanto existencial como ético-social. Esta anotación procede de un Cuaderno de 1973, a raíz de una fecunda relectura de "El balneario", que será también uno de los impulsos para la prefiguración de El cuarto de atrás: "Revivir para El cuarto de atrás el momento de ebullición de mis versos, aquel invierno en Valladolid, mis luchas a solas y a ciegas, rechazando la burguesía y a la par dándome pereza de salir al raso" (2002: 191-192).

Esta ambivalencia entre el deseo de ruptura y el miedo a la libertad facilita la interpretación de poemas como "Desembocadura", "Certeza", “¿Era por aquí?” o "Convalecencia”, en los que una simbología muy personal contrasta con la imaginería más tradicional de otros poemas del mismo ciclo. Recordemos que el miedo al cambio fue la incertidumbre central de las protagonistas de sus primeros relatos desde "Un día de libertad" a Entre visillos, y en relación con este conflicto están sus diálogos con la naturaleza que traslucen la victoria del tiempo natural sobre el tiempo histórico, muy en la línea del lenguaje elusivo y al mismo tiempo alusivo de la poesía española del segundo lustro de 1940 (véase "Batalla perdida" con San Lorenzo de Piñor al fondo).

Destaco en esta conciencia del tiempo de los "Poemas de primera juventud" la noción anticipada de futuro que se trasluce en "Callejón sin salida" o el encuentro con un destino llamado literatura que no admitía vuelta atrás: "Avanzo alegre y sola / en la exacta mañana / por el camino mío que he encontrado / aunque no haya salida" (Martín Gaite, 2010: 606). La pasmosa seguridad en la asunción de esta ruta, aunque todo se ponga en 
contra, vuelve a aparecer en el ya citado "Certeza": "ya sé que es por allí / por dónde quiero ir, / sé por dónde se va. / Mirad, os lo señalo: / por aquella ranura de poniente" (Martín Gaite, 2010: 614).

Prevalece en estos primeros poemas de Martín Gaite una concepción de la poesía como recomposición de una imagen deseada de sí misma, como un ejercicio de entrañamiento frente a la realidad de su entorno, sin dejar de expresar su sospecha en la palabra nombradora, ya que el estadio preverbal es el momento de máxima expresividad. Las palabras nos devuelven "sucedáneos" (Martín Gaite, 2010: 620), mariposas disecadas, cuando queríamos atraparlas al vuelo (El libro de la fiebre articulará la misma experiencia). La sintonía con el neorromanticismo, el registro estilístico hegemónico del segundo lustro de 1940, es evidente, aunque también comprobamos cómo en la primera poesía de nuestra autora se cuelan imágenes dislocadas del irracionalismo postista. Las "verdes palomas" o la perspectiva "mellada contra los andamios" de la luna llena, a la que también ve como un "globo inflado" (2010: 610), nos recuerdan la imaginería del Libro de las algas (1949) de su amigo Ignacio Aldecoa.

\section{UN CICLO INTERMEDIO: POEMAS POSTERIORES}

En junio de 1975 Carmen Martín Gaite, que no publicaba poesía desde sus años universitarios en Salamanca, daba a la luz en la revista La Ilustración Poética Española e Iberoamericana tres composiciones: "Madrid la nuit”, "Libros y papeles” y "¿Quieres jugar?”. Un año más tarde, coincidiendo con los primeros trabajos preparatorios de la colección Libros Hiperión, reúne por primera vez, a propuesta de Jesús Munárriz, una parte de su producción poética bajo el expresivo título de $\mathrm{Arachas}^{2}$.

\footnotetext{
${ }^{2}$ Esta primera edición de 1976 se verá aumentada con nueve poemas en 1986: seis de "Primera juventud" ("Amor muerto", "Espiga sin granar", "Domingo por la tarde", "Sucedáneos", "Batalla perdida", "Convalecencia") y tres en "Poemas recientes" ("Pieza clave”, "¿Qué hacer con las palabras?" y "Todo es un cuento roto en Nueva York"). La edición de 1994 incorporó catorce poemas a una última y nueva sección titulada "Después de todo", donde ya se evalúan los estragos del tiempo. En 2010 reuní póstumamente, en el tercer volumen de sus Obras completas, esta última edición, Después de todo (siempre con el subtítulo de Poesía a rachas), más un apéndice de poemas dispersos ("La barca nevada", "Tres eran tres"), inéditos ("¿Qué cifras y destellos?”, "A la Virgen del Carmen de El Boalo") y uno compuesto con posterioridad a 1994 ("Hace tanto tiempo"). La labor poética de Martín Gaite se completa con la grabación sonora de sus Poemas (Barcelona: Plaza \& Janés, 2001) y con sus traducciones juveniles del poeta rumano Tudor Arghezi ("Los
} 
La locución modal a rachas se carga de significación temporal. La poesía surge como la visita inesperada de un amigo perdido, tiene como única trama conductora el tiempo de la vida y la necesidad de anotar instantes y estados de conciencia que parecen urgentes, pero con la convicción de nunca podrá cazarlos: "Vivo rodeada de papeles sueltos donde he pretendido en vano cazar fantasmas y retener recados importantes, me agarro al lápiz ya por pura inercia, ¿comprende?, sé que es un vicio estúpido, pero me tranquiliza los nervios", leemos en El cuarto de atrás (Martín Gaite, 2008: 1042).

Sin embargo, esta escritura intempestiva fue objeto de una cuidada atención y revisión por parte de la autora. Lo confirma el citado preliminar para la antología Poemas: "El vicio de anotar alguna impresión de esas que caen del cielo como un rayo y estremecen todo nuestro ser no desapareció por completo, ni le cerré la puerta a aquellas fugaces visitas de la poesía" (2010: 595). En el mismo sentido, una anotación con la que inicia un cuaderno de poemas manuscritos (los llamados "Poemas posteriores") reincide en el lugar de honor que estaba dispuesta a dispensar a esa visita intermitente llamada poesía y anuncia el proyecto de recopilar sus poemas:

Mi amigo Moli me trajo de New York este delicado cuadernito chino el 27 de junio de 1975. Todavía no sé a qué lo dedicaré. Tal vez a copiar en limpio poemas viejos y a apuntar otros que se me puedan ir ocurriendo. Me da pena emplearlo para otra cosa. Sólo de eso es digno. Creo, pues, que tan elegante regalo me obligará a volver mi atención hacia la poesía (Martín Gaite, 1975-1989: 3) .

Los "Poemas posteriores" representan, según sus propias palabras, "el salto de la jovencita provinciana y soñadora a la mujer ya afincada en la capital, dueña de su destino y de su casa" (2010: 596). Los incluidos en la "primera entrega" datan de 1969 a 1975, los de la "segunda" fueron

muertos" y "Duhovniceasca", Trabajos y Días, n. ${ }^{\circ}$ 7, 1947), su versión de Viaje hacia el amor y otros poemas, de William Carlos Williams (Madrid: Trieste, 1981), y su traducción de "El cuervo", de Edgar Allan Poe (Cuadernos de la Merced, n. $^{\circ} 2$, junio de 1988), junto a Antonio Bueno Tubía y Francisco Cumpián, con quienes también realizó recitales de poesía en el Café Manuela de la calle San Vicente Ferrer de Madrid, a finales de la década de 1980.

${ }^{3}$ Este cuaderno lo denominamos Cuadernito chino, siguiendo la descripción citada de la autora. El cuaderno autógrafo contiene una copia "en limpio" de las "Diez coplas de amor y desagarro" y ante-textos de los poemas que formarán parte de la sección "Después de todo". 
compuestos desde 1976 (tras la primera edición de $A$ rachas) hasta los meses anteriores a la muerte de su hija Marta, acaecida en abril de 1985.

La noche en la ciudad como espacio de escape, pero con toda la carga irónica y de autoconciencia que supone la mujer madura fugándose a bordo de barcos que se hunden o de trenes que descarrilan (como les ocurrirá a las protagonistas de Nubosidad variable), será un motivo recurrente de este segundo ciclo de poemas, entre los que destaco "Descarrilamiento", en el que se escenifica simbólicamente el despertar magullado tras los excesos nocturnos o la resaca de todos los tinglados fulminantes de un sentido de la irrealidad impropio de una edad. La pregunta retórica de cómo pudo ocurrir el descarrilamiento presta al poema un tono de humor y cinismo, muy del gusto de Jaime Gil de Biedma, a quien va dedicado en la grabación de su antología Poemas. La ironía, el lenguaje coloquial, los temas urbanos y "el Verbo hecho tango" (Gil de Biedma, 2010: 213) de esta sección serán también elementos de contigüidad con otros poetas del medio siglo, como Ángel González, José Agustín Goytisolo y Gabriel Ferrater.

Otro leitmotiv de esta sección (que irá reapareciendo con más vehemencia en el último ciclo poético, "Después de todo", y en su obra narrativa a partir de Retahilas) es la incapacidad de apresar el flujo del tiempo. Su actitud ante el tiempo vivido otorgará a su poesía un aire de autobiografía imaginada en torno a la mujer que fue su autora, porque estamos ante los versos de toda una vida. Si en los primeros poemas había mucho tiempo que perder, en estos penúltimos el tiempo es una categoría inasible, una experiencia que desgasta y de la que comienza a evaluar sus cicatrices. La gran pregunta es cómo abrigarse de la incuria del tiempo y ante dicho dilema surgen la fe y la duda sobre ese otro tiempo gastado en la escritura, tal como se formula en "Libros y papeles". En este monólogo dramático la riña interior entre quien decide quedarse en casa escribiendo (sin saber "si ha salido el sol / o hay gente en el río" [2010: 639]) y quien duda del valor de una "queja disecada" (2010: 639), que solo sirve para llenar estantes y anaqueles, articula la ambivalencia entre la voluntad artística y la vital, una incertidumbre que se disipa al aceptar que su destino es indefectiblemente convertir la vida en palabra o el amargo placer de transformar la escasez en lenguaje.

En este segundo bloque domina el uso del poema-canción y los ritmos tradicionales, ya que algunas de estas composiciones nacieron para 
ser cantadas, como demuestra el repertorio de Chicho Sánchez Ferlosio y de Amancio Prada, con quien colaboró recopilando coplas populares gallegas para el disco Caravel de caraveles (1976). También debemos recordar su juvenil interés universitario por los cancioneros galaicoportugueses, tema sobre el que proyectó su tesis doctoral y que la traerá a Madrid en noviembre de 1948. Algo de ese proyecto inconcluso pervivirá en la antología bilingüe que veinte años más tarde preparó con Andrés Ruiz Tarazona, Ocho siglos de poesía gallega (1972), y en la que Martín Gaite se encargó de la selección y traducción de cantigas hasta el siglo $\mathrm{XV}$. La canción será también un molde propicio para el poema en clave, motivado por algo y alguien, y para el uso del humor, la ironía y hasta la melancolía (tonos compatibles y eficaces en la autora para aludir a la pérdida irremediable de aquel tiempo). Buen ejemplo serán las "Diez coplas de amor y desgarro", escritas a lo largo de la primavera y el otoño de 1972 y probablemente inspiradas en su desafiante relación con Gonzalo Torrente Malvido, tras su separación con Rafael Sánchez Ferlosio. La composición de estas coplas, según demuestra la posición destacada que ocupan en el autógrafo Cuadernito chino y en la primera edición de $A$ rachas (1976 y la reimpresión de 1979), fue fundamental para que Carmen Martín Gaite retomase su atención por su labor poética e incubara el proyecto de publicar un libro.

\section{DESPUÉS DE TODO}

En 1993 Martín Gaite amplía con una nueva sección, “Después de todo", el corpus anterior, y aunque siga manteniendo como subtítulo Poesía a rachas, el nuevo encabezamiento intensifica un sentido del tiempo, que ya fue enunciado en los "Poemas posteriores", pero ahora que se medirá después de todos sus estragos y mudanzas. La pérdida de los grandes asideros en los que se agarró en la vida será el tema central: desde la muerte de su hija Marta (véanse "La última vez que entró Andersen en casa" y "Quien motiva mi queja") a ese tiempo de la experiencia donde acaba el amor y las voces deseo, fe y juego se inscriben como otras palabras disecadas entre las páginas de sus cuadernos ("Chispa de plata antigua", "Farmacia de guardia" y "El cuarto de jugar"). Sin embargo, a pesar de tantos heraldos de derrota del último bloque de su poesía, hay que destacar un rasgo de fe, que fue en el fondo una promesa a la hija muerta de seguir 
viviendo "contra viento y marea", de "recoger la luz de otras miradas" y "el hilo de otros cuentos", de acogerse "impasible al instante presente" (2010: 667). Y en esa promesa, que es toda una declaración vital y literaria de principios, Carmen Martín Gaite, después y a pesar de todo, nunca defraudó (véase "Lo juro por mis muertos").

La conciencia formal de Carmen Martín Gaite a la hora de elaborar su intimidad fue altísima, como demuestran estos poemas últimos y el Cuaderno escrito tras la muerte de Marta, "El otoño de Poughkeepsie". La causa podría encontrarse en su amor por la narración. Narrar para ella era todo lo contrario a pregonar una historia: "No se dice lo secreto, se cuenta [...]. Al pregonero se le paga para que pregone, no para que narre [...]. Lo verdadero es secreto", como leemos en la última edición revisada de Cuadernos de todo (2019: 454). Nuestra autora consiguió siempre evitar la falacia patética y convirtió el descalabro vital en una fuente literaria de conocimiento, asumiendo el viejo mito romántico, tan perceptible en la relación entre su vida y obra, de todo lo que la perjudicó como mujer la benefició como creadora. Martín Gaite hizo literatura con los temas más definitorios de una categoría llamada intimidad (que no conviene confundir con privacidad noticiosa): la soledad, el miedo, el deseo del deseo y la defensa acérrima de su ración de alegría.

\section{LO POÉTICO COMOUNAACTITUD DE ENUNCIACIÓN: RELACIONES ENTRE SU POESÍA Y EL RESTO DE SU OBRA}

La poesía de Martín Gaite no es un pariente marginal de su obra. Considero que ilumina elementos aún no explorados de la misma. Sus novelas - e incluso sus ensayos y Cuadernos de todo - se engrandecen a la luz de las iluminaciones y epifanías que su lenguaje poético revela. Muchos de los personajes de sus narraciones son retratados en sus poemas a las horas más íntimas, en los momentos en que la realidad invisible es percibida por la imaginación. La poesía refuerza la visión central de sus narraciones y los poemas parecen mostrarnos una instantánea sintética, una llamada acuciante o una captura del tiempo en la sucesión de los hechos narrados en cuentos y novelas. Las confluencias temáticas entre algunos de sus composiciones poéticas y el resto de sus obras son muy estrechas, como nos demuestran los propios títulos. El libro de la fiebre se extracta en 
"Convalecencia"; Entre visillos, en "Domingo por la tarde" y "Campana de cristal"; El cuarto de atrás, en "El escondite inglés"; La Reina de las Nieves y "El otoño de Pougkeepsie", en "La última vez que entró Andersen en casa"; Lo raro es vivir, en "Telarañas"; y Caperucita en Manhattan, el cuaderno de collages Visión de Nueva York e incluso las conferencias "La libertad como símbolo" o "El punto de vista", en su poema de 1983 "Todo es un cuento roto en Nueva York", cuyo expresivo título nos remite a cómo cualquier narración de hechos se detiene ante imágenes fugaces que reclaman su derecho a no ser olvidadas. Esas imágenes instantáneas serán rescatadas por la poesía, que en el caso de Martín Gaite tampoco es reducible a un género, sino a una forma de visión, como demuestra su genuino metarrelato, "Flores malva" (Teruel, 2019: 19-20).

Si la poesía fue la primera labor literaria de la autora y complementa el resto de su obra, también conviene reconocer que su capacidad de visión poética, por encima del uso del verso o de la prosa, atravesará toda su escritura narrativa, ensayística y autobiográfica, desde El libro de la fiebre a Los parentescos, desde "Vuestra prisa" a "Pasarela hacia lo desconocido", pasando por sus grandes obras maestras El cuarto de atrás, El cuento de nunca acabar o "El otoño de Poughkeepsie". En su obra narrativa lo poético radica especialmente en un tratamiento del tiempo y del espacio; en su obra ensayística, es un particular punto de vista que consistirá en hablar de sí misma a través de los otros y en no abandonar el aliento de sus propias creencias en el enfoque de un tema abstracto; y en sus Cuadernos de todo lo poético estriba en una concepción episódica de la memoria, propia de una obra compuesta por trozos que siempre vuelven a emerger, pero desde distintos puntos de observación. Poesía, ensayo, narrativa y cuadernos personales son, en su caso, versiones múltiples y simultáneas sobre los mismos hechos y estados de conciencia en los que cuadran mal los preceptivos compartimentos estancos de los géneros literarios. Carmen Martín Gaite, como demuestra la permeabilidad de la edición de sus Obras completas, abrazó todo género que le viniera bien para elaborar su discurso. Y en este punto, quiero formular desde la concepción de la escritura transversal de Rafael Argullol (1996) y desde la teoría sobre la enunciación lírica de José María Pozuelo Yvancos (1998) una hipótesis sobre el lugar de lo poético en su obra.

Considero que la singladura literaria de Martín Gaite demuestra que lo genuinamente poético no reside en la forma ni en el tema, ni siquiera 
en el uso del verso, "sino en un tratamiento temporal de la experiencia humana", que hace caso omiso de una imagen del tiempo concebida como un continuum y "se concentra en determinados focos, cuya especial luz oscurece extensos territorios liberados al olvido" (Argullol, 1996: 14-15). La poesía como la memoria consiste en ese tratamiento del tiempo que saca a flote los vértices decisivos de nuestra existencia, porque hay otro tiempo que nos configura de una manera radicalmente distinta: un tiempo ajeno a toda linealidad, desbocado y caótico. Este otro tiempo, mediante el cual reconocemos el relato secreto de nuestra existencia y que no admite la imagen del orden postizo de la línea recta, sino que por el contrario "se manifiesta en violentas discontinuidades" (Argullol, 1996: 13), es el que quiere revelarnos lo poético.

Buena parte de la poesía como género literario y de toda la obra de Martín Gaite está construida alrededor del deseo de recuperar en puro alud ese asalto del tiempo que se escapa. David Fuente y Andrea Barbero, los personajes centrales de Ritmo lento (1963) y del cuento "Variaciones sobre un tema" (1967), lo manifiestan con la exactitud de los poetas:

No valen de nada los criterios cronológicos para evocar el tiempo pasado. Muchas veces he pensado en la ineficacia de los diarios íntimos [...], en cuanto que pretenden ser arcas donde guardar, día a día, para salvarlo de olvido, lo que solo puede ser salvado echándolo, por el contrario, al olvido mismo [...]. Hay de vez en cuando episodios que no sé dónde están colocados en el tiempo, pero que atraviesan la cortina indiferenciada de las horas y los días, imponiéndose con un perfil neto y único (Martín Gaite, 2008: 509).

El tiempo, pues, venía a estar contenido mucho más en las historias deseadas -narradas a uno mismo o a otro-que en lo ocurrido en medio de fechas. En las fechas era donde se cobijaba la mentira, [...] como si no pudieran pedirse al tiempo más cuentas que las de su coincidencia con los sucesos que había patrocinado; y aunque también ella en muchas ocasiones hubiese tratado de reconstruir el edificio de su edad apuntalándolo contra semejantes datos, sentía ahora que cualquier referencia anecdótica era un espantapájaros colocado para desorientar de una búsqueda verdadera (Martín Gaite, 2010: 150).

La vivencia y la representación del paso del tiempo, la brecha entre el pasado y el presente, la sospecha en el narrar consecuencial, y el acto 
lírico como presencia de las cosas siendo, como vislumbres momentáneas y fulgurantes de percepción, han sido formulados igualmente en dos de sus mejores poemas: "Pájaro vegetal" (titulado en una primera versión inédita "Clamar en el desierto") y "El desorden antiguo". A estos poemas cabe añadir múltiples reflexiones de los Cuadernos de todo, que encierran una "tensión discursiva" cercana a la poesía, en la que "el yo se hace escritura presente, vivencia del tiempo detenido, palabra en el tiempo que se resuelve en instante" (Pozuelo, 2014: 122). La diferencia entre los poemas y las anotaciones narrativas radica en los vacíos situacionales de los primeros frente a la mayor determinación de los espacios enunciativos en las segundas. Entre estas anotaciones destaco la del Cuaderno número 4, fechada en El Boalo, el 31 de julio [de 1964]. En este apunte se intenta esbozar una experiencia subjetiva del tiempo en puro alud: el paseo con su hija, una niña de ocho años, la tarde anterior, por la carretera de la citada localidad de la sierra madrileña, cuando empezaba a anochecer y mientras ese paseo desembocaba inextricable y simultáneamente en otros veranos pretéritos de su infancia en la aldea orensana de San Lorenzo de Piñor. El resultado es una experiencia extática de simultaneidad espacial y temporal, donde lo inabarcable parece que fugazmente pudiera ser abarcado, junto a lo visible y lo invisible. La secuencia en su brevedad es una pesquisa sobre una narración tenazmente anclada en la crisis de la representación verbal, en relación con otros lenguajes artísticos y en competencia con la oralidad:

Pero ahora no puedo reposar en nada de lo que escribo [...]. Ciertamente que el mecanismo de componer una novela ha llegado a no serme extraño, y una nueva novela - después de mis esfuerzos de arquitectura para articular la última - me comprometería a ponerla en pie sin mucha dificultad, casi como quien se echa a andar por unos raíles. Pero son unos raíles que me han aburrido y no me sirven. Nunca es la misma máquina la que tiene que andar por ellos, es una cabezonería empeñarse a adaptarlos a todos los viajes [...]. La novela se ha vuelto una monserga, algo instituido, discreto, acorde. No. ¡No! Hace falta desafinar [...]. Pero ya no sabemos. Tenemos demasiado sentido de la corrección, de lo que es justo, de lo que disuena. Nos alarma la estridencia, el mal gusto [...]. Tal vez la poesía, una forma inédita de poesía sería lo único que pudiera servir ahora [...]. Tampoco la poesía. Sobra lógica. Falta unción, entrega. ¿Qué haré para escribir, para estrellar todo lo que me bulle? ¿Contra qué muro? ¿Dónde dejar la marca? (Martín Gaite, 2019: 192-93). 
En el verano de 1982, dieciocho años después, e inmersa en $E l$ cuento de nunca acabar, ampliará y reelaborará esta misma anotación desde otra perspectiva. La experiencia empírica recreada y su resultado narrativo seguirán siendo los mismos: el colapso de la predicación, la imposibilidad de narrar en los raíles consabidos del género novela la contemplación de una tarde con su hija, la picadura de lo eterno junto a lo efímero; pero la diferencia estriba en que la narración de esa lejana tarde queda ahora engarzada en otro conjunto, el que le posibilita el argumento del nuevo libro: la "ruptura de relaciones" con El cuento de nunca acabar o la dificultad de acabar con ese cuento que solo la muerte quiebra.

Esta anotación es una de las más lúcidas representaciones de Martín Gaite sobre uno de los rasgos fundamentales de la enunciación lírica: cómo representar "la absoluta presencia del acto de pensar ejecutándose" (Pozuelo, 1998: 69). En el mismo sentido, en la última conferencia redactada en vida, "Los viejos en la literatura", nuestra escritora comenta:

Algunos autores, cuando se plantean la necesidad de escribir un diario, tropiezan siempre con el mismo escollo: la resistencia de lo fugaz e inapresable para ser disecado. La poesía es una lucha tenaz y muchas veces fallida por retener el instante en que las cosas hablaron un lenguaje especial y nos incitaron a captar ese recado urgente que apenas insinuado se esconde, dejándonos un sobresalto en la memoria (Martín Gaite, 2017: 1044).

\section{CONCLUSIÓN}

En la poesía de Carmen Martín Gaite conviven múltiples registros: desde el poema canción y el divertimento al poema en clave e incluso hermético, y desde el poema de corte autobiográfico al que se nutre de referencias metalingüísticas. Variedad de registros que remiten al rostro inasible de su autora. Ninguna trama se ha de tener por cierta, como en "Todo es un cuento roto en Nueva York", poema cuyo título y tono incide en la necesidad de sobrepasar las fronteras ortopédicas de los géneros literarios. Toda trama es un espejismo, una silueta vaga, fugaz y discutible que se nos escapa. Solo podremos proyectar su yo sobre una imagen detenida escondido tras ese "Hotel room" del cuadro de Edward Hopper, que representa a una mujer que ya no espera nada y se ha quedado sola entre cuatro paredes, condenada a habitar la soledad o a poblar su 
sonambulismo. Pero de ella vislumbramos una tentación, un proyecto de contarse su vida como un "cuento roto", único recurso al que pudo agarrarse para hacerle frente y aguantarla.

El total de la obra poética de Martín Gaite es una meditación sobre su experiencia, que le permite identificar lo que es permanente y trascendental a lo largo de su existencia, aquello que ha determinado su forma de ser entre los otros. En las novelas, las autoproyecciones de la autora se presentan como ficción y, sin embargo, hay más volumen de la experiencia personal. Y los poemas se presentan como experiencias y, sin embargo, se afirma menos lo accidental del personaje. En el verso hay mayor concentración expresiva, se persigue la intensidad a expensas de la claridad. El verso depara mayor visión; la prosa, mayor recreación, pero con una misma poética: conocer es recordar lo que somos; solo lo afectivo permite sobrepasar los límites temporales; nombrar es sacar los asuntos del caos, aunque suponga una traición de ese mismo caos.

\section{REFERENCIAS BIBLIOGRÁFICAS}

ARGULLOL, R. (1996). El cazador de instantes. Cuadernos de travesía 1990-1995. Barcelona: Destino.

BARTHES, R. (1974). El placer del texto, N. Rosa (trad.). Madrid: Siglo XXI.

BLASCO, J. (2011). Poética de la escritura. El taller del poeta. Ensayo de crítica genética. Valladolid / New York: Cátedra Miguel Delibes.

GENETTE, G. (1993). Ficción y dicción, C. Manzano (trad.). Barcelona: Lumen.

GIL DE BIEDMA, J. (2010). Obras. Poesía y prosa, N. Vélez (ed.). Barcelona: Galaxia Gutenberg / Círculo de Lectores.

JURADO MORALES, J. (2011). "Experiencia vital y escritura poética en Carmen Martín Gaite". Ojáncano. Revista de Literatura Española 40, 39-58 (también en Carmen Martín Gaite, el juego de la vida y la literatura, 4-59. Madrid: Visor Libros, 2018).

MARTÍN GAITE, C. (1947-1948). El paraíso recobrado. En Cuaderno con poemas y reflexiones personales. Manuscrito ES.VIBBCL 2.1.6 $A C M G, 40,25$ de la Biblioteca Digital de Castilla y León: https://bibliotecadigital.jcyl.es/bdcyl/es/consulta/busqueda.cmd 
[16/01/2020].

(1948). Poemas manuscritos en una agenda médica. Manuscrito ES.VIBBCL 2.1.15 $\backslash$ ACMG,24,14 de la Biblioteca Digital de Castilla y León: https://bibliotecadigital.jcyl.es/bdcyl/es/consulta/ busqueda.cmd [16/01/2020].

(1975-1989). Cuadernito chino. En Poemas: Coplas de amor y desgarro. Manuscrito ES.VIBBCL 2.1.15\ACMG,25,8 de la Biblioteca Digital de Castilla y León: https://bibliotecadigital.jcyl. es/bdcyl/es/consulta/busqueda.cmd [09/01/2020].

(2008). Obras completas I. Novelas I (1955-1978), J. Teruel (ed.). Barcelona: Galaxia Gutenberg / Círculo de Lectores.

(2009). Obras completas II. Novelas II (1979-2000), J. Teruel (ed.). Barcelona: Galaxia Gutenberg / Círculo de Lectores. (2010). Obras completas III. Narrativa breve, poesía y teatro, J. Teruel (ed.). Barcelona: Galaxia Gutenberg / Círculo de Lectores. (2015). Obras completas IV. Ensayos I. Investigación histórica, J. Teruel (ed.). Barcelona: Círculo de Lectores / Espasa.

(2016). Obras completas V. Ensayos II. Ensayos literarios, J. Teruel (ed.). Barcelona: Círculo de Lectores / Espasa.

(2017). Obras completas VI. Ensayos III. Artículos, conferencias y ensayos breves, J. Teruel (ed.). Barcelona: Círculo de Lectores / Espasa.

(2019). Obras completas VII. Cuadernos y cartas, J. Teruel (ed.). Barcelona: Círculo de Lectores / Espasa.

MARTÍN GAITE, C. y RUIZ TARAZONA, A. (eds.) (1972). Ocho siglos de poesía gallega. Antología bilingüe. Madrid: Alianza.

NIEMÖLLER, S. (2004). "Después de todo. Poesía a rachas. La obra poética de Carmen Martín Gaite”. En Carmen Martín Gaite, A. Redondo Goicoechea (ed.), 67-80. Madrid: Ediciones del Orto.

PERSIN, M. (1990). “Carmen Martín Gaite's A rachas: Dreams of the Past and Memories of the Future, Text(ure)s, Woven of Many Colored Threads". Monographic Review / Revista Monográfica VI, 93-104. POZUELO YVANCOS, J. M. a (1998). “¿Enunciación lírica?”. En Teoría del poema: la enunciación lírica, F. Cabo Aseguinolaza y G. Gullón (eds.), 41-75. Amsterdam-Atlanta: Rodopi. (2014). "Los Cuadernos de todo y la escritura del yo". En Un lugar llamado Carmen Martín Gaite, J. Teruel y C. Valcárcel (eds.), 109- 
123. Madrid: Siruela.

ROMERO LÓPEZ, D. (2002). "Primeros textos publicados de Carmen Martín Gaite en la revista Trabajos y Días (Salamanca, 1946-1951)". Signa. Revista de la Asociación Española de Semiótica 11, 239-256 (también en http://www.cervantesvirtual.com/obra-visor/signarevista-de-la-asociacion-espanola-de-semiotica-5/html/025dabac82b2-11df-acc7-002185ce6064_25.html [28/01/2020]).

TERUEL, J. (2007). "La expresión poética en Carmen Martín Gaite". Turia 83, 236-245.

(2019). "La extrañeza ante lo cotidiano". Prólogo a Todos los cuentos, Carmen Martín Gaite, 9-21. Madrid: Siruela.

WOOD, J. (2014). “Poesía a ráfagas': Carmen Martín Gaite's Early Poetic Voice". Espéculo. Revista de Estudios Literarios 52, 123 124, http://webs.ucm.es/info/especulo/Carmen_Martin_Gaite_ Especulo_52_2014_UCM.pdf [16/01/2020].

Recibido el 27 de enero de 2020.

Aceptado el 20 de abril de 2020. 